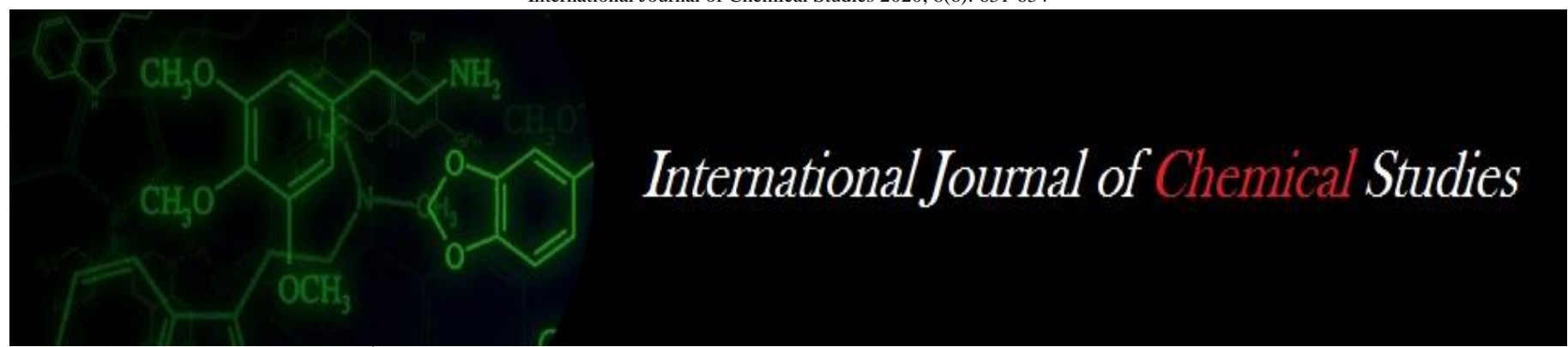

P-ISSN: 2349-8528

E-ISSN: 2321-4902

www.chemijournal.com

IJCS 2020; 8(6): 631-634

(C) 2020 IJCS

Received: 19-09-2020

Accepted: 30-10-2020

\section{Hiren Das}

Department of Soil Science and Agricultural Chemistry, College of Agriculture, Central

Agricultural University, Imphal, Manipur, India

\section{N Surbala Devi}

Department of Soil Science and Agricultural Chemistry, College of Agriculture, Central

Agricultural University, Imphal, Manipur, India

\section{RK Kumarjit Singh}

Department of Soil Science and Agricultural Chemistry, College of Agriculture, Central Agricultural University, Imphal, Manipur, India

\section{A Herojit Singh}

Department of Soil Science and Agricultural Chemistry, College of Agriculture, Central

Agricultural University, Imphal,

Manipur, India

L Nabachandra Singh

Department of Soil Science and Agricultural Chemistry, College of Agriculture, Central

Agricultural University, Imphal Manipur, India

\section{N Gopimohan Singh}

Department of Soil Science and

Agricultural Chemistry, College of Agriculture, Central

Agricultural University, Imphal, Manipur, India

\section{Corresponding Author:}

\section{Hiren Das}

Department of Soil Science and Agricultural Chemistry, College of Agriculture, Central

Agricultural University, Imphal, Manipur, India

\section{Influence of boron and lime on boron concentration and dry matter yield of green gram (Vigna radiata $\mathbf{L}$.)}

\author{
Hiren Das, N Surbala Devi, RK Kumarjit Singh, A Herojit Singh, L \\ Nabachandra Singh and N Gopimohan Singh
}

DOI: https://doi.org/10.22271/chemi.2020.v8.i6i.10843

\begin{abstract}
A pot experiment was conducted during 2019 pre-kharif season in acid soil at College of Agriculture, Iroisemba, Cental Agricultural University, Imphal to investigate the effect of five levels of boron (viz., 0 , $0.5,1,1.5$ and $2 \mathrm{~kg} \mathrm{~B} \mathrm{ha}^{-1}$ ) and two levels of lime (L1=unlimed and L2=limed) on boron concentration and dry matter yield of green gram (Vigna radiata L.) variety DGGS-4. Results revealed that irrespective of different treatments there was an increasing trend of plant boron concentration and dry matter yield up to harvest of the crop. Significantly higher boron concentration and dry matter yield were recorded in green gram grown in soil added with boron over control at different crop growth stages. Application of boron in absence of lime resulted in an increase in boron content of greengram. Irrespective of boron application, liming enhanced dry matter yield of the crop. The combined application of lime and boron at $2 \mathrm{~kg} \mathrm{ha}^{-1}$ enhanced the dry matter yield of green gram followed by addition of lime and $1.5 \mathrm{~kg} \mathrm{~B} \mathrm{ha}^{-1}$ at different growth stages. This shows higher agronomic efficiency of boron and lime.
\end{abstract}

Keywords: Boron, lime, boron concentration, dry matter yield and green gram

\section{Introduction}

India is the world's largest producer as well as consumer of green gram. It produces about 1.5 to 2.0 million tonnes of moong from about 3 to 4 million hectares of area with an average productivity of $500 \mathrm{~kg} \mathrm{ha}^{-1}$. Green gram output account for about 10 to $12 \%$ of total pulses production in the country. Pulses form an integral part of vegetarian diet of large population of India. It is used as an ingredient in both savory and sweet dishes. (Fuller and Harvey, 2006) [6]. Similar to the leguminous pulses, green gram, enriches soil nitrogen content. It also plays an important role in maintaining and improving the fertility of soil through its ability to fix atmospheric nitrogen in the soil by root nodules. Nodule formation on the roots of green gram through Rhizobium bacteria, fix about $35 \mathrm{~kg} \mathrm{ha}^{-1}$ atmospheric nitrogen (Yadav, 1992) [26]. It also gives palatable and nutritious fodder for cattle ( $\mathrm{Lal}, 1976){ }^{[13]}$. The Indian people are predominantly vegetarian; the pulses are an indispensable part of the diet as it contains $23.1 \%$ protein which is nearly two and half times more than the cereals, 0.5 to 4.33 per cent fats and 23.4 to 66.3 per cent carbohydrates (Sinha, 1977) ${ }^{[23]}$.

The role of micronutrients in achieving nutritional security to satisfy the burgeoning population is well known and is gaining more importance in present. Among the micronutrients, the deficiency of boron (B) is most widespread in acid soils. It has a close relationship with calcium both in soil and in plant. $\mathrm{Ca}$ increases the $\mathrm{B}$ requirement of plants due to similarity in function (Golakiya and Patel, 1986) ${ }^{[8]}$. Boron is an essential micronutrient which is required for growth of the plant and is directly and indirectly involved in many plant metabolic functions. It helps in proper division and elongation of cell, promotes cell wall strength, flowering, pollination, seed set and translocation of sugar (Dordas, 2006 and Takano et al., 2008) ${ }^{[4,24]}$. Boron deficiency is commonly observed in light-textured acidic soils, in soils with high amount of calcium carbonate $\left(\mathrm{CaCO}_{3}\right)$ or oxides and hydrous oxides of iron $(\mathrm{Fe})$ and aluminium $(\mathrm{Al})$, and in soils with low organic-matter content. Its deficiencies are related to high rain fall areas with acidic soil environment. Under acid soil conditions, boron is more water soluble and can therefore be leached below the root-zones of plants by rainfall. 
The range between deficiency and toxicity is very narrow and hence boron needs judicious fertility management. Its quantitative requirement is very low depending on the crop. Seed yield and its quality in crop plants are greatly influenced by both macro and micronutrients Jasim et al. (2014) ${ }^{[11]}$. Micronutrients like Boron also have the significant effect to achieve the potential yield of mungbean. Thus, the application of B not only increased the yield but also improved the quality of green gram. Proper management of these micronutrients in acid soils is found to be extremely important in sustaining higher crop yields (Singh, 2001; Bhupalraj et al., 2005 and Singh, 2006) ${ }^{[22,2,21]}$. The present investigation was undertaken to study the effect of boron and lime on boron concentration and dry matter yield of green gram (variety DGGS-4) in an acid soil.

\section{Materials and Methods}

A pot experiments was conducted at the Department of Soil Science and Agricultural Chemistry, College of Agriculture, Iroisemba, Central Agricultural University, Imphal during pre-Kharif 2019, to study the effect of boron and lime on boron concentration and dry matter yield of green gram (Vigna radiata L.) variety DGGS-4. For the study an acidic soil was collected from the research farm of the College of Agriculture, Central Agricultural University, Iroisemba, Imphal by taking several thin slices from the surface layer ( 0 $20 \mathrm{~cm}$ depth) as outlined by Jackson (1973) ${ }^{[10]}$. The general characteristics of the soil are presented in Table 1.

Five $\mathrm{kg}$ each of air dried soil was taken in a series of pots. The required quantity of $\mathrm{N}\left(20 \mathrm{kgha}^{-1}\right), \mathrm{P}_{2} \mathrm{O}_{5}\left(40 \mathrm{kgha}^{-1}\right)$ and $\mathrm{K}_{2} \mathrm{O}\left(20 \mathrm{kgha}^{-1}\right)$ were applied to all the pots as basal dose through urea and SSP and MOP and also mixed properly in the soil. Lime was added 14 days before sowing as per treatment. Lime requirement was determined by SMP buffer method (Shoemaker et al., 1961) ${ }^{[20]}$. According to different set of treatments, five levels of boron $\left(B 1=0 \mathrm{~kg} \mathrm{ha}^{-1}, \mathrm{~B} 2=0.5\right.$ $\mathrm{kg} \mathrm{ha}^{-1}, \mathrm{~B} 3=1.0 \mathrm{~kg} \mathrm{ha}^{-1}, \mathrm{~B} 4=1.5 \mathrm{~kg} \mathrm{ha}^{-1}$ and B5=2.0 kg ha-1) with the source of boric acid (B-17\%) and lime as liming material at two levels (L1=unlimed and L2=limed) were mixed thoroughly with the soil. Four to five seeds of green gram var. DGGS-4 were sown in each pot and after germination only one plant per pot is maintained. The pots were irrigated with water throughout the crop growth period, while maintaining $60 \%$ water holding capacity (WHC).

The whole plants were collected on $15^{\text {th }}, 30^{\text {th }}, 45^{\text {th }}$ and $60^{\text {th }}$ days after sowing (DAS) and at harvest by destructive sampling. The collected plant samples were washed properly with tap water and finally rinsed with deionized water. The plant material was then dried at $60^{\circ} \mathrm{C}$ for 48 hours in a hot air oven and dry matter yield was recorded. The dried plant samples of each treatments were powdered in stainless steel grinder and kept for dry ashing in a muffle furnace at $550^{\circ} \mathrm{C}$ for 5 hours and then ash was extracted in $10 \mathrm{~mL} 0.36 \mathrm{~N} \mathrm{H}_{2} \mathrm{SO}_{4}$ for 1 hour at room temperature as described by Gaines and Mitchell (1979) [7]. Plant boron uptake was determined colorimetrically by using azomethine-H method at $420 \mathrm{~nm}$ wavelengths. Soil texture, $\mathrm{pH}, \mathrm{EC}$, organic carbon, CEC, available $\mathrm{N}, \mathrm{P}$ and $\mathrm{K}$ were determined following the standard procedures as described by Jackson (1973) ${ }^{[10]}$.

The experiment was carried out under factorial randomized block design (FRBD) with total ten treatments replicated thrice was employed. All the data pertaining to the investigation was statistically analysed through analysis of variance technique for comparing the treatments effects. The significance of various effects was tested at 5\% level of probability.

\section{Result and Discussion}

\subsection{Effect of Boron and Lime on boron concentration in green gram}

Result on changes in the amount of boron concentration in green gram grown in soil applied with boron and lime are shown in Table 1. Results showed that irrespective of different treatments there was an increasing trend of plant boron content with crop growth till harvest. Comparing with untreated control, significantly higher boron was accumulated in plants grown in soil added with boron at different stages of crop growth. This is at par with the findings of Sharma et al. (1999) [19]; Mandal and Das (2011) ${ }^{[14]}$ and Sarkar and Devi (2020) ${ }^{[17]}$. Further study revealed significantly enhanced boron accumulation with increasing dose of boron application in each successive sampling days i.e., 15, 30, 60 and 90 days after sowing and at harvest. This increase in boron concentration in plant can be attributed to the higher uptake of boron from the soil. Mani and Haldar (1996) ${ }^{[15]}$ also observed similar results. Among the different boron levels comparatively higher plant boron content was recorded in soil applied with $2 \mathrm{~kg} \mathrm{~B} \mathrm{ha}^{-1}$ followed by $1.5 \mathrm{~kg} \mathrm{~B} \mathrm{ha}^{-1}$ and $1.0 \mathrm{~kg}$ $\mathrm{B} \mathrm{ha}{ }^{-1}$. Further it was observed that comparatively higher boron content at different green gram growth stages was found in unlimed soil over the limed. The decrease in plant boron concentration with liming confirms lower extractable boron content in lime treated soils. Similar negative effect of liming on the boron concentration in plant was reported earlier (Dwivedi et al., 1992; Tsadilas and Kassioti, 2005 and Chaudhuary and Debnath, 2008) ${ }^{[5,25,3]}$.

Critical study of the Table 2 showed that the interactive effect of Lime and applied Boron was also statistically significant. It was revealed from critical analysis of data that the interaction of boron and lime significantly affected the boron concentration of green gram throughout the entire experiment. Interaction effect revealed that statistically higher boron content was observed in unlimed soil applied with $2 \mathrm{~kg} \mathrm{~B}^{-1}$ followed by unlimed soil with $1.5 \mathrm{~kg} \mathrm{~B} \mathrm{ha}^{-1}$ during the whole growth stages of green gram.

\subsection{Effect of Boron and Lime on dry matter yield of green gram}

Table 3 represents the results of changes in the dry matter yield of green gram plants as affected by application of lime and boron. In general, irrespective of different treatments an increase in the dry matter yield of green gram up to harvest was recorded. Similar report on increasing trend of dry matter yield with crop growth was also reported earlier by Sarkar and Surbala (2020) ${ }^{[17]}$. Significantly higher dry matter yield of green gram was observed in soil treated with boron over control on $30^{\text {th }}$ days after sowing onwards till harvest. During this stages dry matter yield was increased significantly with the increasing levels of boron. The applied boron is more efficient in increasing the dry matter yield of green gram. Mani and Haldar, (1996) ${ }^{[15]}$; Sarkar et al. (2008) ${ }^{[18]}$; Barman et al. (2014) [1]; Movalia et al. (2018) ${ }^{[16]}$ and Sarkar and Surbala (2020) ${ }^{[17]}$ presented similar results on enhanced dry matter yield due to boron application. Comparison among the different boron treatments, significantly higher dry matter yield was observed in soil treated with $2 \mathrm{~kg} \mathrm{ha}^{-1}$ followed by $1.5 \mathrm{~kg} \mathrm{ha}^{-1}$ at different green gram growth stages.

Further study revealed that, irrespective of different boron levels, application of lime resulted in significantly enhanced dry matter yield during the whole crop growth stages. This is at par with the records of Kamboj and Malik (2018) ${ }^{[12]}$ and Movalia et al. (2018) ${ }^{[16]}$. 
It was observed from further study that, the combined effect of lime and boron application had a beneficial effect on the dry matter yield of green gram over that in the control during the whole growing stages of the crop. This is at par with the findings of Mani and Haldar (1996) ${ }^{[15]}$. Critical study of the interaction effect revealed that statistically higher dry matter yield was recorded in limed soil applied with boron at $2 \mathrm{~kg} \mathrm{ha}$ ${ }^{1}$ followed by limed soil with $1.5 \mathrm{~kg} \mathrm{~B} \mathrm{ha}^{-1}$ from $30^{\text {th }}$ day onwards till harvest.

Table 1: General characteristics of the soil used in the experiment

\begin{tabular}{|c|c|}
\hline Soil Characteristics & Results \\
\hline Textural Class & Clay \\
\hline Sand (\%) & 24.32 \\
\hline Silt (\%) & 21.01 \\
\hline Clay (\%) & 54.67 \\
\hline $\mathrm{pH}(1: 2.5$ Soil: water ratio) & 5.2 \\
\hline $\mathrm{EC}\left(1: 2.5\right.$ Soil: water ratio, $\left.\mathrm{dSm}^{-1}\right)$ & 0.15 \\
\hline CEC [cmol $\left.\left(\mathrm{p}^{+}\right) \mathrm{kg}^{-1}\right]$ & 17.2 \\
\hline Organic carbon $(\%)$ & 1.18 \\
\hline Available nitrogen $\left(\mathrm{kg} \mathrm{ha}^{-1}\right)$ & 274.59 \\
\hline Available phosphorus $\left(\mathrm{kg} \mathrm{ha}^{-1}\right)$ & 19.20 \\
\hline Available potassium $\left(\mathrm{kg} \mathrm{ha}^{-1}\right)$ & 208.37 \\
\hline
\end{tabular}

Table 2: Effect of boron and lime on boron concentration (ppm) in green gram

\begin{tabular}{|c|c|c|c|c|c|c|c|c|c|c|c|c|c|c|c|}
\hline Treatments & \multicolumn{3}{|c|}{15 DAS } & \multicolumn{3}{|c|}{30 DAS } & \multicolumn{3}{|c|}{45 DAS } & \multicolumn{3}{|c|}{60 DAS } & \multicolumn{3}{|c|}{ HARVEST } \\
\hline BORON/FYM & L1 & L2 & MEAN & L1 & L2 & MEAN & L1 & $\mathbf{L 2}$ & MEAN & L1 & L2 & MEAN & L1 & L2 & MEAN \\
\hline B1 & 1.11 & 0.99 & 1.05 & 2.01 & 1.80 & 1.91 & 4.00 & 3.60 & 3.80 & 5.00 & 5.23 & 5.12 & 5.40 & 6.00 & 5.70 \\
\hline B2 & 1.61 & 1.28 & 1.44 & 2.42 & 2.11 & 2.26 & 4.80 & 4.20 & 4.50 & 5.90 & 5.53 & 5.72 & 6.60 & 6.37 & 6.49 \\
\hline B3 & 2.34 & 1.77 & 2.05 & 3.14 & 2.51 & 2.82 & 6.20 & 5.00 & 5.60 & 7.60 & 6.60 & 7.10 & 8.00 & 7.00 & 7.50 \\
\hline B4 & 3.74 & 1.81 & 2.77 & 4.56 & 2.64 & 3.60 & 9.00 & 5.40 & 7.20 & 9.80 & 6.80 & 8.30 & 10.67 & 7.40 & 9.03 \\
\hline B5 & 4.55 & 3.16 & 3.85 & 5.35 & 3.95 & 4.65 & 10.60 & 7.80 & 9.20 & 11.20 & 9.60 & 10.40 & 11.40 & 10.27 & 10.83 \\
\hline Mean & 2.67 & 1.80 & & 3.50 & 2.60 & & \multicolumn{3}{|c|}{\begin{tabular}{|l|l|}
6.92 & 5.20 \\
\end{tabular}} & 7.90 & 6.75 & & 8.41 & 7.41 & \\
\hline Source & \multicolumn{2}{|l|}{$\mathrm{SE}(\mathrm{d})$} & CD0.05 & \multicolumn{2}{|c|}{$\mathrm{SE}(\mathrm{d})$} & CD0.05 & $\mathrm{SE}(\mathrm{d})$ & & CD0.05 & SE(d) & \multicolumn{2}{|c|}{ CD0.05 } & \multicolumn{3}{|c|}{ SE(d) CD0.05 } \\
\hline B & \multicolumn{2}{|l|}{0.06} & 0.13 & \multicolumn{2}{|l|}{0.07} & 0.15 & 0.15 & & 0.31 & 0.14 & \multicolumn{2}{|l|}{0.30} & 0.13 & \multicolumn{2}{|l|}{0.28} \\
\hline $\mathrm{L}$ & \multicolumn{2}{|l|}{0.04} & 0.08 & \multicolumn{2}{|l|}{0.04} & 0.09 & 0.09 & & 0.20 & 0.09 & \multicolumn{2}{|l|}{0.19} & 0.09 & \multicolumn{2}{|l|}{0.18} \\
\hline BXL & \multicolumn{2}{|l|}{0.09} & 0.18 & \multicolumn{2}{|l|}{0.10} & 0.21 & 0.21 & & 0.44 & 0.20 & \multicolumn{2}{|l|}{0.42} & 0.19 & \multicolumn{2}{|l|}{0.40} \\
\hline & \multicolumn{3}{|c|}{$\mathrm{B} 1=$ Boron $0 \mathrm{~kg} / \mathrm{h}$} & \multicolumn{3}{|c|}{$\mathrm{B} 4=$ Boron $1.5 \mathrm{~kg} / \mathrm{ha}$} & $\mathrm{L} 1=$ & Unlit & med & $\mathrm{SE}(\mathrm{d})$ & Standa & d error o & mean di & ifferen & \\
\hline & $\mathrm{B} 2=$ & Boron & $0.5 \mathrm{~kg} / \mathrm{ha}$ & $\mathrm{B} 5=1$ & 3oron & $2.0 \mathrm{~kg} / \mathrm{ha}$ & & $=\mathrm{Li}$ & ned & $5=c$ & $\mathrm{cald}$ & ence at & $\%$ level & of $\mathrm{p}$ & obability \\
\hline & B3 = & orc & $0 \mathrm{~kg} / \mathrm{ha}$ & & & & & & & & & & & & \\
\hline
\end{tabular}

Table 3: Effect of boron and lime on dry matter yield $\left(\mathrm{g} \mathrm{pot}^{-1}\right)$ of green gram

\begin{tabular}{|c|c|c|c|c|c|c|c|c|c|c|c|c|c|c|c|}
\hline \multirow{2}{*}{\begin{tabular}{|c|} 
Treatments \\
BORON/FYM \\
\end{tabular}} & \multicolumn{3}{|c|}{15 DAS } & \multicolumn{3}{|c|}{30 DAS } & \multicolumn{3}{|c|}{45 DAS } & \multicolumn{3}{|c|}{60 DAS } & \multicolumn{3}{|c|}{ HARVEST } \\
\hline & L1 & L2 & MEAN & L1 & L2 & MEAN & L1 & L2 & MEAN & L1 & L2 & MEAN & L1 & L2 & MEAN \\
\hline B1 & 0.46 & 0.85 & 0.66 & 0.99 & 1.16 & 1.08 & 3.61 & 4.71 & 4.16 & 7.04 & 8.49 & 7.77 & 8.32 & 10.02 & 9.17 \\
\hline B2 & 0.52 & \begin{tabular}{|l|}
0.87 \\
\end{tabular} & 0.70 & 1.25 & 1.69 & 1.47 & 4.21 & 5.07 & 4.64 & 7.59 & 8.76 & 8.18 & 9.28 & 10.88 & 10.08 \\
\hline B3 & 0.67 & \begin{tabular}{|l|}
0.92 \\
\end{tabular} & 0.80 & 1.07 & 1.93 & 1.50 & 3.98 & 5.90 & 4.94 & 7.74 & 9.63 & 8.69 & 9.96 & 11.19 & 10.58 \\
\hline B4 & 0.73 & 0.94 & 0.84 & 1.55 & 2.39 & 1.97 & 4.48 & 6.02 & 5.25 & 8.07 & 9.99 & 9.03 & 10.47 & 11.95 & 11.21 \\
\hline B5 & 0.82 & 0.99 & 0.90 & 1.96 & 2.54 & 2.25 & 4.96 & 6.15 & 5.56 & 8.93 & 10.35 & 9.64 & 11.02 & 12.49 & 11.76 \\
\hline Mean & 0.64 & 0.91 & & 1.36 & 1.94 & & 4.25 & 5.57 & & 7.87 & 9.44 & & 9.81 & 11.31 & \\
\hline Source & \multicolumn{2}{|c|}{$\mathrm{SE}(\mathrm{d})$} & CD0.05 & \multicolumn{2}{|c|}{$\mathrm{SE}(\mathrm{d})$} & CD0.05 & \multicolumn{2}{|c|}{ SE(d) } & CD0.05 & $\mathrm{SE}(\mathrm{d})$ & \multicolumn{2}{|c|}{ CD0.05 } & SE(d) & \multicolumn{2}{|c|}{ CD0.05 } \\
\hline $\mathrm{B}$ & \multicolumn{2}{|c|}{0.023} & 0.049 & \multicolumn{2}{|c|}{0.010} & 0.021 & \multicolumn{2}{|c|}{0.012} & 0.025 & 0.015 & \multicolumn{2}{|c|}{0.032} & 0.017 & \multicolumn{2}{|c|}{0.35} \\
\hline $\mathrm{L}$ & \multicolumn{2}{|c|}{0.015} & 0.031 & \multicolumn{2}{|c|}{0.006} & 0.013 & \multicolumn{2}{|c|}{0.007} & 0.016 & 0.010 & \multicolumn{2}{|c|}{0.020} & 0.011 & \multicolumn{2}{|c|}{0.022} \\
\hline BXL & \multicolumn{2}{|c|}{0.033} & 0.070 & \multicolumn{2}{|c|}{0.014} & 0.030 & \multicolumn{2}{|c|}{0.017} & 0.035 & 0.021 & \multicolumn{2}{|c|}{0.045} & 0.024 & \multicolumn{2}{|c|}{0.050} \\
\hline & \multicolumn{3}{|c|}{$\mathrm{B} 1=$ Boron $0 \mathrm{~kg} / \mathrm{h}$} & \multicolumn{3}{|c|}{ B4 = Boron $1.5 \mathrm{~kg} / \mathrm{ha}$} & $\mathrm{L} 1=$ & $=\mathrm{Un}$ & med & \multicolumn{6}{|c|}{ SE $(d)=$ Standard error of mean difference } \\
\hline & \multicolumn{3}{|c|}{$\mathrm{B} 2=$ Boron $0.5 \mathrm{~kg} / \mathrm{ha}$} & \multirow{2}{*}{\multicolumn{3}{|c|}{ B5 = Boron $2.0 \mathrm{~kg} / \mathrm{ha}$}} & & & & 年 & 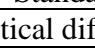 & & $\%$ leve & of pro & obabili \\
\hline & B3 = & Bor & $.0 \mathrm{~kg} / \mathrm{ha}$ & & & & & & & & & & & & \\
\hline
\end{tabular}

\section{Conclusion}

Based on the results as explained above, it can be concluded that application of boron resulted in an increased boron concentration and dry matter yield of green gram at different stages of crop growth. Liming enhanced dry matter yield of the crop with reduction in plant boron content. The combined application of lime and boron at $2 \mathrm{~kg} \mathrm{ha}^{-1}$ enhanced the dry matter yield of green gram followed by lime and $1.5 \mathrm{~kg} \mathrm{~B} \mathrm{ha-1}$ application at different growth stages showing higher agronomic efficiency.

\section{References}

1. Barman M, Shukla LM, Datta SP, Rattan RK. Effect of applied lime and boron on the availability of nutrients in an acid soil. Journal of Plant Nutrition 2014;37(3): 357373.

2. Bhupalraj G, Patnaik MC, Khadke KM. Molybdenum status in soils of Andhra Pradesh. Progress report of All India coordinated researh project on micro and secondary nutrients and pollutant elements in soils and plants of Andhra Pradesh. ANGRAU, Hyderabad 2005;25:1-123. 
3. Chaudhury SG, Debnath A. Effect of liming on retention and availability of boron in Entisol and Alfisol. Journal of the Indian Society of Soil Science 2008;56(1):64-70.

4. Dordas C. Foliar boron application improves seed set, seed yield, and seed quality of alfalfa. Agronomy Journal 2006;98(4):907-913.

5. Dwivedi BS, Ram M, Singh BP, Das M, Prasad RN. Effect of liming on boron nutrition of pea (Pisum sativum L.) and corn (Zea mays L.) grown in sequence in an acid Alfisol. Fertilizer research 1992;31(3):257-262.

6. Fuller DQ, Harvey E. The archaeobotany of Indian Pulses: identification, processing and evidence for cultivation. Environmental Archaeology 2006;11(2):219246.

7. Gaines TP, Mitchell GA. Boron determination in plant tissue by the azomethine-H method. Communications in Soil Scince and Plant Analysis 1979;10:1099-1108.

8. Golakiya BA, Patel MS. Effect of Calcium carbonate and boron on yield of groundnut. Indian Journal of Agricutural Sciences (India) 1986;56(1):41-44.

9. Gupta UC, Macleod JA. Plant and soil boron as influenced by soil $\mathrm{pH}$ and calcium sources on podzol soils. Soil Science 1981;131(1):20.

10. Jackson ML. Soil Chemical Analysis. Prentice Hall of India Pvt. Ltd., New Delhi 1973.

11. Jasim AH, Obaid AS. Effect of foliar fertilizers spray, boron and their interaction on broad bean (Vicia faba L.) yield. Scientific Papers Series B. Horticulture 2014;58:271-276.

12. Kamboj N, Malik RS. Influence of phosphorous and boron application on Yield, Quality, Nutrient content and Their Uptake by Green Gram (Vigna radiate L.). International Journal of Current Microbiology and Applied Science 2018;7(3):1451-1458.

13. Lal S. Relationship between grain and biological yields in chickpea (Cicer arietinum L.). Tropical Grain legume Bulletin 1976;6:29-31.

14. Mandal M, Kumar Das D. Effect of boron management on the yield of rape (Brassica campestris) and its mobility in soil and plant. Indian Journal of Agricultural Sciences 2011;81:1180.

15. Mani PK, Haldar M. Effect of dolomite on boron transformation in acid soil in relation to nutrition of green gram. Journal of the Indian Society of Soil Science 1996;44(3):458-461.

16. Movalia JA, Parmar KB, Vekaria LC. Effect of boron and molybdenum on yield and yield attributes of summer green gram (Vigna radiata L.) under medium black calcareous soils. International Journal of Chemical Studies 2018;6(1):321-323.

17. Sarkar A, Devi NS. Effect of boron and farmyard manure application on boron concentration and dry matter yield of paddy. International Journal of Chemical Studies 2020;8(1):1374-1376.

18. Sarkar D, Mandal B, Mazumdar D. Plant availability of boron in acid soils as assessed by different extractants. Journal of Plant Nutrition and Soil Science 2008;171(2):249-254.

19. Sharma KR, Srivastava PC, Ghosh D, Gangwar MS. Effect of boron and farmyard manure application on growth, yields, and boron nutrition of sunflower. Journal of plant nutrition 1999;22:633-640.

20. Shoemaker HE, McLean EO, Pratt PF. Buffer methods for determining lime requirement of soils with appreciable amounts of extractable aluminum 1. Soil Science Society of America Journal 1961;25(4):274-277.

21. Singh MV. Micro and secondary nutrients and pollutant element Research in India. AICRP Micronutrient, IISS, Bhopal 2006;26:1-82.

22. Singh MV. Response of micronutrient to crops in different agro-ecological regions- Experiences of AICRP Micronutrients. Fertiliser News 2001;46:43-49.

23. Sinha SK. Food Legumes: Distribution, Adaptability and Biology of Yield. FAO plant production and protection pap.3, Rome 1977.

24. Takano J, Miwa K, Fujiwara T. Boron transport mechanisms: collaboration of channels and transporters. Trends in plant science 2008;13(8):451-457.

25. Tsadilas CD, Kassioti T, Mitsios IK. Influence of liming and nitrogen forms on boron uptake by tobacco. Communications in soil science and plant analysis 2005;36(4-6):701-708.

26. Yadav DS. Pulse crop. Kalyani publisher, New Delhi 1992, 14-21. 